\title{
A CHALLENGE TO ALL AUTHORITIES: D.H. LAWRENCE'S PROVOCATIVE REMOTE SOUTH
}

Stefania Michelucci, University of Genoa, Italy, Stefania.Michelucci@unige.it

\begin{abstract}
From his first travel book Twilight in Italy (1916) to the posthumously published Etruscan Places (1932), Lawrence's travel writing shows a continuous experimentation with the genre, which in his hands, always escapes any fixed scheme. In spite of their stylistic difference and the variety of images and contents, his travel books lay bare a common intention, which is the author's attempt to escape the wasteland of mechanization and industrialization, the upsetting, fragmented world of Europe at the time of World War I, and to find an ideal place for a rebirth, a palingenesis, a place (remote in space and, in the case of Etruscan Places, also in time) where human beings could live an harmonious relationship with Nature, with the Other and with the Self.
\end{abstract}

Keywords: D.H. Lawrence, destination, exile, travel writing, time, space, contamination, culture, nature, otherness, Etruria, Rome, authority.

\section{Introduction}

The British writer D.H. Lawrence (1885-1930) is an extremely prolific artist whose production includes, besides a group of paintings, many literary works belonging to all genres. He was also a writer in transit who, at the beginning of the $20^{\text {th }}$ century, travelled all over the world: in the short span of his life Lawrence visited many countries, encountering and adjusting to a variety of places and cultural realities (Sri Lanka, Australia, Mexico, New Mexico, etc.). In Europe, he stayed for varying lengths of time in Germany, France, Switzerland, and Spain, but it was only in Italy that he chose to live, settling in different places (from the beautiful Lake Garda in the North of the country, to Sicily, to isolated, uncouth, and at that time little known places, such as Picinisco in the Abruzzi mountains and Sardinia, to the beautiful countryside of Tuscany). Many of his journeys and sojourns also provided the inspiration for his work, including travel writings (Twilight in Italy, Sea and Sardinia, Sketches of Etruscan Places), as well as short stories, novels, and poems ("Sun," "Smile," Aaron's Rod, The Lost Girl, 
the poems "Cypresses," "The Ship of Death," etc.), and other nonfictional writings ("David," "Fireworks in Florence," "Flowery Tuscany"), to mention just a few. ${ }^{1}$

Lawrence's first journey to Italy took place in 1912, one of the most important years in his life, when he left England, with its philistine, repressive culture, and his job as a teacher, and went first to Germany and then to Italy with a married woman, Frieda Weekley (born von Richthofen). They spent eight months in Gargnano on Lake Garda, an experience which is recalled in the essays collected in Twilight in Italy (1916). Not only was he attracted by the place and the people, but he also got involved in the literary and artistic turmoil which was taking place in Italian culture at the beginning of the $20^{\text {th }}$ century. ${ }^{2}$ Suffice it to think of Marinetti and Futurism, with which he developed a sort of love-hate, attraction-rejection relationship, and which was destined to have an enormous influence on his life and work, an influence which is still, in my opinion, underrated by critics. It is in the last years of his life, in the bucolic peace and serenity of the Tuscan countryside, at the Villa Mirenda in Scandicci, near Florence that Lawrence experiences a period of intense artistic creativity in spite of the illness which is slowly gnawing at his body. Here he completes his last novel, Lady Chatterley's Lover (1928), a challenge to the prudery of his countrymen, but also an attempt to outline the way to regeneration to the Western World, a way which is also pointed to in the collections of poems Pansies, Nettles and Last Poems, as well as in his paintings. ${ }^{3}$

\section{A Tiresome Journey to an Underground World}

In spite of the weakness caused by his illness, in 1926 and 1927 Lawrence visits some Etruscan sites with his American friend, the painter Earl Brewster; the interest in the Etruscans had been stimulated by a former visit to Tuscany in September 1920. The poem

\footnotetext{
${ }^{1}$ I would like to add that Twilight in Italy has been chosen and selected by John Carey for his Guide to the $20^{\text {th }}$ century's most Enjoyable books, Faber, 2000.

${ }^{2}$ He tried (successfully) to learn Italian: he had a teacher in Gargnano, and could write letters in Italian when he was staying at the Villa Mirenda in 1927/28. See for example his letters to Giulia Pini in The Letters of D.H. Lawrence, vol. VII, 1928-1930, edited by Keith Sagar and James T. Boulton, Cambridge: CUP, 1994. He also translated from Italian the novel Mastro Don Gesualdo_and some short stories by the famous Sicilian writer Giovanni Verga, and A. F. Grazzini's Story of Doctor Manente.

${ }^{3}$ Cfr. John Worthen, D.H. Lawrence: The Life on An Outsider, London: Counterpoint, 2005. See also The Cambridge Biography of D.H. Lawrence, 3 vols. by John Worthen, Mark Kinkead-Weekes and David Ellis, Cambridge: CUP, reissue edition, 2014.
} 
"Cypresses" (1920), "The underliverable secret, / Dead with a dead race and a dead speech...," written as a result of that visit to Tuscany, as well as a passage in the travel book, Sea and Sardinia, about "the strange 'shrouded gods' of the Etruscans," are a kind of poetic expression of the interpretation he would subsequently develop (Lawrence 2008: 27). ${ }^{4}$

The interest in the Etruscan world had also been stimulated by such authoritative texts as The Cities and Cemeteries of Etruria, (1907) by George Dennis, ${ }^{5}$ Etruskiche Malerei (1921) by Fritz Weege, Roland Arthur Lonsdale Fell's book Etruria and Rome (Cambridge, 1924), as well as the Italian Etruria Antica by Pericle Ducati (1925), which Lawrence quotes in Sketches of Etruscan Places, constantly questioning their scholarly interpretations. He had also been attracted by emerging studies on ancient civilizations, by anthropological texts such as Sir James Frazer's The Golden Bough, Jane Harrison's Ancient Art and Ritual (1913), and Emile Durkheim's The Elementary Form of Religious Life, which he read with great interest and from which he developed a kind of "religious yearning" (according to Mark Kinkead-Weekes). The contact with the past was for Lawrence an important stage in the development of his dream of achieving "wholeness," that is, a total harmony between body, mind and soul. In the foreword to his second book on his theory of the unconscious, Fantasia of the Unconscious, Lawrence attributes to ancient civilizations some kind of deep life knowledge, which is completely lost and unknown to modern humanity:

I honestly think that the great pagan world of which Egypt and Greece were the last living terms, the great pagan world which preceded our own era once, had a vast and perhaps perfect science of its own, a science in terms of life. In our era this science crumbled into magic and charlatanry. But even wisdom crumbles [...] Then came the world flood [...]. The refugees [...]. Fled [...]. and some like Druids or Etruscan or Chaldeans or Amerindians or Chinese, refused to forget, but taught the old

\footnotetext{
${ }^{4}$ See D.H. Lawrence, The Poems, edited by Christopher Pollnitz, Cambridge: CUP, 2013.

${ }^{5}$ Dennis's travel book is very personal and lively, full of vitality and humour. Massimo Pallottino wrote in his monumental work Etruscologia (1942) that Dennis was an explorer, who approached the remains as evidence of a living people.
} 
wisdom, only in its half-forgotten, symbolic forms. (Lawrence 2014: 54)

It was only during his last Italian sojourn in Tuscany that Lawrence seriously thought of the Etruscans as a possible subject for a book, and planned a visit to Etruscan sites, which were not very far away.

In the spring of 1926 he visited Perugia and the National Archaeological Museum, famous for its Etruscan Urns ("Etruscan things [...] have a great attraction for me: there are lovely things in the Etruscan Museum here" [Lawrence 1989: 464]), and he planned to visit a few cities for the book he had in mind which had to be "half travelbook, half scientific too":

What I should most like to do, for the trip, would be to do the western half of the Etruscans - the Rome museums - then Veii and Cività Castellana and Cerveteri - which one does from Rome - then Corneto, just beyond Cività Vecchia in Maremma - then the Maremma coast-line and Volterra [...] If there were time, we might get to Chiusi and Orvieto - we could see. I have a real feeling about the Etruscans. (Letter to Earl Brewster, 6 March 1927, Lawrence 1989: 649-650) ${ }^{7}$

Owing to ill health, Lawrence was unable to visit all the sites he had hoped to see, and he wrote only six of the twelve sketches he had originally planned. The book he had envisaged thus remained unfinished, though the six completed essays were collected posthumously as Etruscan Places. Four of the essays were published separately in the periodicals Travel in America and World Today in Britain.

\section{2. "The Etruscans were young in their vitality": Lawrence's Destabilization of Authoritative Historians}

The fact that so little was known about the Etruscans and their civilization helped to stimulate Lawrence's imagination and curiosity, and gave him the opportunity to interpret freely the Etruscan remains

\footnotetext{
${ }^{6}$ Cfr. D.H. Lawrence, Phychoanalysis and the Unconscious and Fantasia of the Unconscious, edited by Bruce Steele, Cambridge: CUP, 2014.

${ }^{7}$ Corneto was an ancient name for a town which developed near the old Etruscan city; the Fascist regime restored the Roman name.
} 
in terms of those symbols which best expressed his own ideas. For centuries historians, archaeologists, linguists and scholars had tried to penetrate the mystery of the Etruscans, to explain their origin, to read their language, to interpret their symbols. Lawrence was inevitably tempted to try his own interpretation of that ancient world and came to see the Etruscan civilization as the symbol of a lost vitality. By travelling backwards in time, he tried to recapture the spontaneity and the sense of wonder which he had perceived in the culture of the Native Americans and which he felt had been an important feature in the life of the Etruscans. He was inspired by a civilization that had lived according to an ideal of life which seemed to correspond to his own: the Etruscan culture represented the old order, the pagan world retaining all the virtues he associated with the pre-Christian world, which he felt he had experienced in Cornwall during the years of World War I:

It seems as if the truth were still living here, growing like the sea holly. [...] I do like Cornwall [...] One can feel free here [...] feel the world as it was in that flicker of pre-Christian Celtic civilization, when humanity was really young. (Lawrence 1982: 492, 495)

For Lawrence, the Etruscans were "young" in their vitality, yet they were also the keepers of the old, great secret of life, and when finally he came to write his book, they were to symbolize naturalness, spontaneity, and simplicity - aspects of a civilization which was antithetical to the modern, mechanical, and corrupted one. The old secret mentioned in the poem "Cypresses" was lost with the Etruscans, and so - for Lawrence - human beings are no longer able to understand the real meaning of life: "We are really far, far more lifestupid than the dead Greeks or the lost Etruscans" (Lawrence 1982: 118).

Lawrence's own Etruscan tour took place a year later, in April 1927, when Lawrence visited Cerveteri, Tarquinia, Vulci and Volterra and recounted his impressions in a series of essays, Sketches of Etruscan Places.

Sketches of Etruscan Places has a special place among Lawrence's travel books: as he himself explained, he wanted to write a work which would be, "half travel-book, half scientific too." Sketches of Etruscan Places gives details of the route one has to follow to reach each place, the means of transportation available, the topography of the area, hotels and eating places, and so on. This is, however, only 
"half the book" (Lawrence 1989: 412). The other 'half' gives detailed information about the structure of the tombs and archaeological treasures found there, about museums and their contents, along with some historical notes on the Etruscan world. This part is therefore, as Lawrence defined it, more scientific, or - better - it is a questioning of the established scientific authorities on the subject.

As Lawrence wrote in a letter to Millicent Beveridge about Roland Arthur Lonsdale Fell's book from 1924, Etruria and Rome:

He's very thorough in washing out once more the few rags of information we have concerning the Etruscans: but not a thing he has to say. It's really disheartening: I shall just have to start in and go ahead, and be damned to all authorities! There is really next to nothing to be said, scientifically, about the Etruscans. Must take the imaginative line. (8 June 1926; Lawrence 1989: 473)

No original written sources on the history of the Etruscans have survived, and early writing about them was filtered through the culture of their conquerors, the Romans. From the very beginning of his book, Lawrence firmly rejects the view of prestigious nineteenthcentury historians such as Theodor Mommsen, who was preoccupied with the celebration of Rome's grandeur and was incapable of giving an unbiased account of the Etruscans.

"A great scientific historian like Mommsen hardly allows that the Etruscan existed at all. Their existence was antipathetic to him" (Lawrence, 1992: 9). ${ }^{8}$ Such historians had transmitted the image of the Etruscans as a depraved, weak people who deserved to be wiped out by Roman expansion. ${ }^{9}$ This consideration helped Lawrence to follow

\footnotetext{
${ }^{8}$ Theodor Mommsen (nobel prize 1902), Romische Geschichte (1-3, 1854-56, 8 vols. Munchen, 2001), The History of Rome, trans. W.P. Dickson, 1894, reprinted in 1996, vol. I, chapt. 9, "The Etruscans," p. 150: The Etruscans' "religion presenting a gloomy fantastic character and delighting in the mystical handling of numbers and in wild and horrible speculations and practices, is equally remote from the clear rationalism of the Romans and the genial image-worship of the Hellenes." Lawrence ironically writes about him: "The Prussian in him was enthralled by the Prussian in all conquering Romans. So being a scientific historian, he almost denies the very existence of the Etruscan people." (Cfr. Lawrence, 1992: 9)

${ }^{9}$ Especially the women who, because of the freedom, independence and public role they had, shocked Greek and Roman travellers and historians who considered them lost women, prostitutes.
} 
his own "imaginative line" (Lawrence 1989: 473). ${ }^{10}$ His artistic sensitivity enabled him to treat his subject with a special, lively, intuitive insight never shown before by any Etruscologist, as one of the most important scholars in the field of Etruscan Studies, Massimo Pallottino, has pointed out. ${ }^{11}$

The Etruscans have inspired powerful pulsing pages in contemporary literature, especially English Literature, like Lawrence in Etruscan Places, as well as Huxley in his novels, Those Barren Leaves and Point Counter Point, through which the interpretation of Ancient Etruria symbolically turns into a celebration of the lost world, of a humanity which was spontaneously natural, happy, living within and through the body, opposed to the rational and moral order of the Greek and Roman civilization and culture, as well as Christian. (Massimo Pallottino, "L'Etruria di Huxley e Lawrence," in the catalogue of the exhibition, Les Etrusques et L'Europe 1992).

The scholar who will one day write that history of Etruscans art which has not yet been written, will have to take into account Lawrence's observations which [...] contain a much more valid critical quality [...] than the many huge volumes published by well-known archeologists [...] The Etruscologist cannot ignore the charm that the object of his studies exerts in the world of culture so widely [...] In this respect [...] science may once more acknowledge his debt to poetry. (Massimo Pallottino, Scienza e poesia alla scoperta dell'Etruria, a lecture written in 1957 and published as an Introduction to the Italian Edition of Etruscan Places, Paesi Etruschi, 1985, ed. Giovanni Kezich, Siena: Nuova Immagine Editrice, p. 26).

\footnotetext{
${ }^{10}$ Lawrence seems to be partly in the tradition of George Dennis, whose Cities and Cemeteries of Etruria he had read years before. Dennis's study of the Etruscans is, like Lawrence's, very lively, and shows an interest not only in the archaeological remains, but also in the people met in the tour and in the "living" places visited, as he gives a description of the inhabited modern towns. As Simonetta de Filippis points out in her Introduction to Sketches of Etruscan Places, compared to The Cities and Cemeteries of Etruria, however, Lawrence's book, has an additional fundamental quality, his intuitive insight into the lost culture.

${ }^{11}$ Les Etrusques et l'Europe staged in Paris in 1992 and in Berlin in 1993 (published in Italy as Gli Etruschi e l'Europa, Milano: Fabbri 1992, pp. 150-152). See also Jean-Marc Irollo, Gli Etruschi. Alle origini della nostra civiltà, Bari: Dedalo, 2008.
} 


\section{References:}

Dennis, George. Cities and Cemeteries of Etruria. London: J. Murray, 1848.

Irollo, Jean-Marc. Gli Etruschi. Alle origini della nostra civiltà. Bari: Dedalo, 2008.

Lawrence, D.H. Birds, Beasts and Flowers. With an Introduction by Keith Cushman. New Hampshire: The Black Sparrow Press, 2008.

Lawrence, D.H. Twilight in Italy and Other Essays, ed. Paul Eggert, with Introduction and Notes by Stefania Michelucci. Penguin: London, 2007.

Lawrence, D.H. Phychoanalysis and the Unconscious and Fantasia of the Unconscious. Ed. Bruce Steele, Cambridge: CUP, 2014.

Lawrence, D.H. Sketches of Etruscan Places and Other Italian Essays. Ed. Simonetta de Filippis. Cambridge: CUP, 1992.

Lawrence, D.H. The Poems. Ed. Christopher Pollnitz. Cambridge: CUP, 2013.

Lawrence, D.H. The Letters of D.H. Lawrence. Vol. II. Ed. George J. Zytaruk and James T. Boulton. Cambridge: CUP, 1982.

Lawrence, D.H. The Letters of D.H. Lawrence. Vol. V. Ed. James T. Boulton and Lindeth Vasey, Cambridge: CUP, 1989.

Momnsen, Theodor. Roemische Geschichte. 8 vols. Muenchen: 2001.

Pallottino, Massimo. Etruscologia (1941). VII edition. Milano: Hoepli, 2016.

Pallottino, Massimo. Gli etruschi e l'Europa. Milano: Fabbri, 1992.

Pallottino, Massimo. "Scienza e poesia alla scoperta dellâ Etruria." Paesi Etruschi. Ed. Giovanni Kezich. Siena: Nuova Immagine Editrice, 1985.

Worthen, John. D.H. Lawrence: The Life on An Outsider. London: Counterpoint, 2005.

Worthen, John, Kinkead-Weekes, Mark and Ellis, David. The Cambridge Biography of D.H. Lawrence. 3 vols. Cambridge: CUP, reissue edition, 2014.

\section{SFIDARE L'AUTORITA: IL SUD REMOTO E PROVOCATORIO DI D.H. LAWRENCE}

Dal primo libro di viaggio Twilight in Italy (1916) al postumo Etruscan Places (1932), i libri di viaggio di Lawrence mostrano un'inarrestabile sperimentazione con il genere letterario della 
letteraturea di viaggio, che esula sempre da ogni schema. Nonostante la loro diversità stilistica e la loro molteplicità di immagini e contenuti, i libri di viaggio lawrenciani svelano un fine comune, ossia il tentative dell'autore di fuggire dalla meccanizzata e industrializzata 'terra desolata' del vecchio continente, dalla sconvolgente e fragmentata realtà europea della prima Guerra mondiale e di trovare un luogo ideale per una rinascita, una palingenesi, un luogo spazialmente e, nel caso dell'ultimo libro di viaggio anche temporalmente, remoto, dove l'essere umano possa vivere in armonia con la Natura, con l'altro e con se stesso.

Parole chiave: D.H. Lawrence, esilio, letteratura di viaggio, tempo, spazio, contaminazione, cultura, natura, alterità, Etruria, Roma, autorità. 